\title{
GRADING THE PERFORMANCE OF A LEGISLATOR
}

\author{
Leo J. RASKIND* \\ I \\ INTRODUCTION
}

How should the contribution of a legislator be measured? The thesis of this festschrift article is that appropriate performance criteria, akin to a baseball player's statistics, can describe and assess a legislative career. While such criteria may lack the precision of the athlete's numbers, they can serve well enough to help locate the overall performance of a legislator along a meaningful continuum-serving as a cat's paw of special interest groups at one end and being an effective representative of the public interest at the other.

Representative Kastenmeier emerges at the end of the spectrum that describes the ideal public servant. Setting aside the complex elements of voter satisfaction, a legislator may be assessed in an arena of peer professionals. It is this latter aspect of his record that is the focus of this essay. From the perspective of an academic copyright lawyer, a legislator may be judged on his mastery of the substantive material, on his aptitude for asserting the public interest among special interest proposals, and by his ethical standards. On all these counts, Kastenmeier is entitled to high marks.

\section{Legislative Performance Criteria}

The task of crafting legislative performance criteria necessarily begins with the legislative process itself and with the substantial literature that it has generated. Since early in this century, the structure and function of the legislative body in a democratic society has long been the object of scholarly attention by political scientists and economists. ${ }^{1}$ There is a reprise of this basic literature in the current writings of law teachers applying public choice

Copyright $\odot 1992$ by Law and Contemporary Problems

* Visiting Professor of Law, Brooklyn Law School; University Of Miami Law School.

I am pleased to acknowledge the constructive comments on an earlier draft by Michael Klipper, Michael Remington, and Richard H. Stern.

1. John Stuart Mill, Considerations on Representative Government (Harper \& Brothers, 1862); Anthony Downs, An Economic Theory of Democracy (Harper, 1957); Mancur Olson, The Logic of Collective Action: Public Goods and the Theory of Groups (Harvard U Press, 1965); Kenneth J. Arrow, Social Choice and Individual Values (Wiley, 2d ed 1963); James M. Buchanan \& Robert D. Tollison, eds, Theory of Public Choice: Political Applications of Economics (U of Michigan, 1972); James M. Buchanan, Constitutional Economics? (Blackwell, 1991). 
theory. ${ }^{2}$ To the extent that this varied literature has a common theme, it is the continuous concern with the impact of special interest groups. While there is consensus within this literature on the potentially corrosive effect of special interest lobbying, this literature has not produced a general theory to explain or predict the dynamics of the formation and the effect of special interest activity.

The initial work was done by political scientists who studied the influence of special interest groups on specific legislation. ${ }^{3}$ As the literature developed, the several disciplines began to construct models and prepare case studies of the involvement of special interest groups in the legislative process generally. ${ }^{4}$ Some of these writers concluded that the legislature functioned as an arena in which special interests are competitors for the attention of the elected representatives. ${ }^{5}$ Recent federal income tax legislation has been described in such terms:

[We] see important institutions-Congress, the Treasury, the business lobbying forces, even the outgunned public policy advocates - at work. . . Congress, especially the House, ... is often like a seamless web of floating coalitions. ${ }^{6}$

The current political science writing rejects as without empirical foundation the conclusion of the earlier writers who viewed special interest groups as merely reflecting the pluralistic dispersion of power in society. ${ }^{7}$ From that earlier perspective, the interaction of the interest groups tended to resolve policy differences by an equilibrium solution that provided sound public policy. Current data show that interest groups form and function largely to support business interests, leaving substantial segments of society unrepresented. Accordingly, special interest groups are more likely to

2. For a comprehensive review of the literature, see Einer R. Elhauge, Does Interest Group Theory Justify More Intrusive Judicial Review?, 101 Yale L J 31, 35-44 (1991). See also Daniel A. Farber \& Philip P. Frickey, Law and Public Choice: A Critical Introduction ch 1 (U Chicago Press, 1991).

3. Elmer E. Schattschneider, Politics, Pressures, and The Tariff: A Study of Free Private Enterprise in Pressure Politics, as Shown in the 1929-1930 Revision of the Tariff (Prentice-Hall, 1935) (documenting the influence of special interest groups on the Smoot-Hawley Tariff Act of 1930).

4. William H. Riker, The Theory of Political Collations (Yale U Press, 1962); James Q. Wilson, Political Organizations ch 15 (Basic Books, 1973); Jeffrey M. Berry, Lobbying for the People: The Political Behavior of Interest Groups (Princeton U Press, 1977); Andrew S. McFarland, Common Cause: Lobbying in the Public Interest (Chatham House Publishers, 1984).

5. For this perspective, "[ $t]$ he legislature referees the group struggle, ratifies the victories of the successful coalitions, and records the terms of the surrenders, compromises, and conquests in the form of statutes. ... What may be called public policy is the equilibrium reached in this struggle ... it represents a balance which the contending factions of groups constantly strive to weight in their favor." Earl Latham, The Group Basis of Politics: A Study in Basing-Point Legislation 35-37 (Cornell U Press, 1952).

6. Jeffrey H. Birnbaum \& Alan S. Murray, Showdown At Gucci Gulch: Lawmakers, Lobbyists, and the Unlikely Triumph of Tax Reform xv, 16-17 (Random House, 1988). For a comprehensive, critical analysis of public choice theory applied to federal income tax legislation, see Daniel Shaviro, Beyond Public Choice and Public Interest: A Study of the Legislative Process as illustrated by Tax Legislation in the 1980s, 139 U Pa L Rev 1 (1990).

7. Charles E. Lindblom, The Intelligence of Democracy: Decision Making Through Mutual Adjustment 242 (Free Press, 1965). 
dominate business-related legislation. ${ }^{8}$ Interest groups do not interact to achieve optimal public policy solutions.

Current political science literature directly examines the impact of special interest lobbying on specific legislation. This approach identifies winners and losers by examining the costs and benefits that specific legislation has imposed or conferred on various groups in society.

Some policies-for example, social security, Medicare, or national defense-confer benefits on large numbers of persons at a cost that all or most of society must pay. . . Sometimes policies confer benefits on one narrowly concentrated, identifiable group and impose costs on another narrowly concentrated, identifiable group. For example, when Congress approves subsidies to sugar beet farmers, it creates benefits for some farmers but imposes higher production costs on candy and soft drink manufacturers. ${ }^{9}$

Unlike the earlier approach that considered the legislator a passive broker among the special interest groups, the recent literature emphasizes the interaction between the legislator and the interest groups. The elected representative is a material actor who participates in the legislative process by performing various alternative roles.

[The legislator] can seek . . . a reputation as a national leader [or] work at press relations, ... be a local civic leader ... or make a reputation in the field of legislation $\ldots$ or conduct investigations ... . The one thing the [legislator] cannot do is much of all these things. [The legislator] must choose among them . . . to be a certain kind of congressman. ${ }^{10}$

The law and economics writers reinforce this perception of the legislator as a rational, maximizing actor. In their terms,

[legislators are] not ... mere ... brokers [acting] in response to competing private demands, but [are] independent actors making their own demands to which private actors respond. ... Political office confers a property right, not just to legislate rents, but to impose costs. A politician can gain by forebearing from exercising his right to impose burdensome restrictions on private actors. ${ }^{11}$

This cursory summary of the contemporary literature suggests two relevant criteria for assessing a legislator's contribution. First, the measures enacted during the legislator's tenure must be parsed to determine whether specific, narrow group goals were systematically achieved to the detriment of the public interest. This review would include hearings, committee reports, and statements in the Congressional Record. The events leading to the enactment of various measures must be studied as well as all versions of the bills as they moved toward enactment.

The second criteria for assessing a legislator's contribution complements and may be merged with the first. The role of the legislator should not be

8. Kay L. Schlozman \& John T. Tierney, Organized Interests and American Democracy $82-87$ (Harper \& Row, 1986) (concluding on the basis of an exhaustive empirical study of special interest groups that (1) special interest representation is not limited to the legislative process, but functions also in campaign financing and related aspects of electoral politics, and (2) activity at the legislative level must be considered in terms of specific legislation).

9. Id at 83-84.

10. Raymond A. Bauer, Ithiel de Sola Pool \& Lewis A. Dexter, American Business and Public Policy: the Politics of Foreign Trade 406-07 (Atherton Press, 2d ed 1972).

11. Fred S. McChesney, Rent Extraction and Rent Creation in the Economic Theory of Regulation, $16 \mathrm{~J}$ Legal Studies 101, 102 (1987). 
reviewed from the paper trail of legislation alone, but also from the "testimony" of the legislator and other participants. The objective is to characterize the conduct of the legislator in examining, questioning, rejecting, modifying, or following special interest positions in relation to the public interest. Here it would be necessary to speak with staff members, lobbyists, and other participants in shaping the legislation. Where it is not practical to obtain a full record of events, reliance has to be made on the best evidence rule.

\section{SPECIAL INTEREST LEgisLATION}

An appropriate starting place to review Congressman Kastenmeier's performance is the copious paper record generated by the hearings leading to the Copyright Act of 1976.12 From these hearings, it is apparent that special interest groups pervaded the legislative process; interest group representatives appeared and testified on virtually every topic. ${ }^{13}$ Indeed, Congressman Kastenmeier himself commented during the course of the hearings that "all interests in this bill were in one form or another, special interests." 14

This should not be considered an "admission" of the subservient role of Congressman Kastenmeier to the special interests in copyright legislation, however. Copyright law itself is "special interest" in nature. Unlike environmental protection legislation, for example, which is designed to insure interests of the population as a whole, copyright law began and remains to protect the interests of a select segment of society as part of a larger design of serving the public interest. ${ }^{15}$

Moreover, copyright legislation is characterized by a limited institutional support structure which provides the legislator with only limited institutional assistance in determining the public interest in a given special interest proposal. For example, as compared to a legislator on a tax writing committee, the copyright legislator has fewer staff and less alternative institutional assistance in discerning the public interest on a given issue. ${ }^{16}$ To be sure, the copyright issues are fewer than those involving the Internal Revenue Code and its some seven thousand provisions, but the substantial difference in support is disproportionately less for copyright legislation.

12. 17 USC $\S \S 101$ et seq (1991).

13. See Hearings on HR 2223 before the Subcommittee on Courts, Civil Liberties, and the Administration of Justice of the House Judiciary Committee, 94th Cong, 1st Sess (1975). See also Jessica D. Litman, Copyright, Compromise, and Legislative History, 72 Cornell L Rev 857 (1987).

14. Hearings on HR 2223 at 1853 (cited in note 13). See also Litman, 72 Cornell L Rev at 870 (cited in note 13).

15. See note 24 and accompanying text.

16. As part of the Library of Congress, the Copyright Office has five operating divisions concerned with processing copyright registrations and small legal staffs of about a dozen lawyers in two of the divisions: the General Counsel's Office and the Policy Planning Advisors. See The United States Government Manual 56 (1990/91). 
The legislator on the House or Senate committee dealing with copyright has only the support of other agencies of the legislative branch, the Copyright Office, and the Office of Technology Assessment, to assist in defining the public interest in the welter of industry presentations. In addition, the copyright committee has the power to appoint a national study commission as was done in 1979 to address the issue of protection of new technologies, including computer programs. ${ }^{17}$ By comparison, a legislator on a House or Senate tax writing committee is assisted in defining the public interest by the executive branch, both the White House and the Treasury, as well as by legislative branch organizations such as the Joint Committee on Taxation and the Congressional Budget Office.

While this legislative framework places more responsibility on the individual legislator in determining the public interest in matters of copyright, the structure of the copyright statute itself fosters the formation of special interest groups by its descriptions of protected interests. Historically, the copyright statute had been "class" legislation affecting the immediate economic interests of creative persons. The general public welfare is the derivative beneficiary of copyright legislation; the creators of the works are the immediate beneficiaries. ${ }^{18}$

By identifying the work products of the creative segments of society, the copyright statute facilitates the formation of special interest groups. Thus, for example, by extending protection to eight kinds of creative works, Section 102 of the Copyright Act ${ }^{19}$ identifies the persons whose works are protected and provides an incentive for these individuals to organize in order to maximize the scope of protection.

This statutory foundation also shapes the relationship of these groups to the legislator. As each interest group presses its position, another group usually presents a countervailing proposal. Thus, some group claims will be met only at the expense of other groups. For example, amending the statute to deprive state institutions of the protection of sovereign immunity in cases of copyright infringement advances the interests of authors of computer software programs at the expense of state universities and other state agencies. $^{20}$

Given this context, the legislative hearings on copyright matters are essentially adversarial. The legislator serves first as a referee and ultimately as the gatekeeper of the public interest. In this second role, the legislator must assess, select, modify, or reject these competing claims in accord with his own

17. See Final Report, National Commission on New Technological Uses ("CONTU") of Copyrighted Works 13-19 (1979) ("Commission's Final Report").

18. See note 24 and accompanying text.

19. Literary works (including computer programs), musical works and their lyrics, dramatic works, including accompanying music, pantomimes and choreographic works, pictorial, graphic, and sculptural works (including maps), motion pictures and other audiovisuals, sound recordings, and architectural works. 17 USC $\$ \$ 102(a)(1)-(8)(1990)$.

20. Congress exercised its right to abrogate the sovereign immunity of states from liability for money damages for copyright infringement in the Copyright Remedy Clarification Act of 1990, Pub L No 101-553, 104 Stat 2749 (1990). 
determination of the public interest. Since special interest groups originate in the copyright statute itself, copyright representatives, unlike special interest representatives in trade legislation, environmental protection, and federal income taxation, for example, have more clearly defined channels in which to protect or expand their statutory turf. Although the scope and number of issues may be smaller than in these other legislative arenas, the pressures are no less intense.

The significance of the interest groups being identified by the statute is underscored by a comparison with the Internal Revenue Code. Unlike the copyright statute, which was designed to serve a special segment of society, the Internal Revenue Code is a statute designed to touch and concern all citizens. Citizenship is its only criterion of jurisdiction. ${ }^{21}$

The statutory objective of the tax code is to impose the tax burden fairly on each income group. ${ }^{22}$ The Code reflects this objective by operative provisions written in broad, generic terms. This general statutory framework provides the objective for special interest groups to form, to define their own interests in the narrowest terms, and to unite in a concerted effort to bend and distort the code's general language for the benefit of that particular group of taxpayers. Thus, in most cases, the identification and impetus for lobbying groups to form is entirely external to the Code. For example, timber and other resource interest groups are essentially defined by geography; banks and insurance interests are defined by their function and by their discrete regulatory legislation. Trade associations are formed in the unregulated sectors of the economy by function, for example, associations of farmers, manufacturers, and motion picture producers. The lobbyists' handiwork is reflected in the multitude of special interest exceptions to the general provisions of the Code. As one commentator has described this process,

[i]ndividuals who appear before [Congress] hardly represent a cross section of opinion on tax matters. . . The result is that, day after day, the committees are subject to a drumfire of complaints against the tax system, arguments against the elimination of special tax advantages, and reasons for additional preferences. ... Whether taxes are to be raised or lowered, most of the witnesses find good reason for favoring the groups or individuals they represent. ${ }^{23}$

Conversely, because copyright legislation was structured by Congress to grant protection to certain creative activities deemed consistent with the public interest, ${ }^{24}$ the ubiquitous presence of special interest groups in intellectual property legislation takes on less of a pejorative connotation.

21. Cook v Tait, 265 US 47, 56 (1924) (U.S. citizens may be taxed on their world-wide income by virtue of their citizenship).

22. Joseph A. Pechman, Federal Tax Policy 63 (Brookings Inst, 5th ed 1987).

23. Id at 55 .

24. In Sony Corp. of America v Universal City Studios, 464 US 417, 429 (1984), the Court identified this balance as follows:

The monopoly privileges that Congress may authorize are neither unlimited nor primarily designed to provide a special private benefit. Rather, the limited grant is a means by which an important public purpose may be achieved. It is intended to motivate the creative activity of authors and inventors by the provision of a special reward, and to allow the public access to the products of their genius .... 
Indeed, Congressman Kastenmeier voiced this sentiment during the hearings on the 1976 Act in a colloquy with the Register, when he said in response to her use of the phrase "special interest," "I do not think we should use the term 'special interest' in the derogatory sense." 25

While too much should not be made of the distinction between the formation and function of special interest groups under these two statutes, the comparison illuminates the differences in the manner in which the legislator in each arena is subject to influence, and aids in the assessment of each legislator's performance. The tax lobbyist appeals to the legislator to modify a particular Code section or general statutory policy in order to attain a departure from the statutory norm for the benefit of the claimant group. ${ }^{26}$ Thus, the tax lobbyists direct their efforts to the legislator in terms of a particular resource, enterprise, or geographic factor. In the typical case, one lobbyist's objective is not opposed by another lobbying group because favorable tax treatment for one class of taxpayers need not directly affect any other interest group. Generally, the cost of selective, favorable tax treatment for one group of taxpayers is reflected in lost revenue by the Treasury and the correlative departure from the principle of tax equity.

By comparison, the pursuit of special interest in the copyright arena is more of a zero-sum game. Treating hospital room displays as public performances requiring payment of royalties favors owners of audio visuals by imposing costs on hospital patients. Thus, a diagrammatic representation of the relationship of the tax lobbyist to the legislator would show a single line of advocacy moving from the lobbyist to the legislator. ${ }^{27}$ In some cases, tax lobbyists form a coalition so that there would be multiple lines from several lobbyists advocating the same modification; for example, the timber interest lobbyist may form a coalition with other groups either along resource lines (coal, natural gas, or oil) or result lines, such as receiving preferential amortization deductions for a group of resources. Thus, in both focus and direction, the tax lobbyists differ from their copyright counterparts.

The lines of persuasion originating with the copyright lobbyist also move to the legislator initially, but typically energize opposing interest groups. Thus the diagrammatic representation would show a line of advocacy from the lobbyist to the legislator as well as a countervailing line of advocacy from the affected group to the legislator. Accordingly, as noted above, the copyright legislator is cast in the role of a referee between these adversaries, at least in the first instance. For example, when during the 1976 revision the

25. Hearings on HR 2223 at 1853 (cited in note 13).

26. Stanley S. Surrey, The Congress and the Tax Lobbyist-How Special Tax Provisions Get Enacted, 70 Harv L Rev 1145, 1146-47 (1957). The role of special interest groups formed to protect a given industry is noted in the deliberations surrounding the Tax Reform Act of 1986 as follows: "The Packwood package retained existing law for almost every tax break associated with the timber, mining, agriculture, and oil and gas industries." Birnbaum \& Murray, Showdown Al Gucci Gulch at 199 (cited in note 6).

27. One commentator has characterized tax lobbyists as "being brought down by the narrowness of their vision." Birnbaum \& Murray, Showdown at Gucci Gulch at 287 (cited in note 6). 
educational establishment as users sought an express statutory exemption permitting multiple copying for classroom use, the publishers' representatives appeared in opposition. ${ }^{28}$ Publishers' representatives again appeared in opposition when the semiconductor chip industry sought protection under the copyright statute with an expanded definition of "fair use" under the broader rubric of "reverse engineering." 29 As part of this same process, the deliberations over the Computer Software Rental Amendments Act of $1990^{30}$ elicited controversy among the video game manufacturers, the rental store owners, and the video game operators.

\section{IV}

\section{In Pursuit of the Public Interest}

A proper assessment of the performance of a copyright legislator should take into account the other aspect of the constitutional mandate: to provide an incentive to create for the benefit of society as a whole. ${ }^{31}$ Thus, copyright legislators should not be evaluated for their involvement with special interest legislation. Rather, their conduct in pursuing the public interest among the welter of competing narrow interest claims should be examined.

To accomplish this task, "public interest" must be defined in the copyright context. Here, too, the Internal Revenue Code serves as a useful benchmark. The public interest in tax legislation may be identified in terms of the dynamics described above, as diagrammed vectors of forces in which the force of special interest ultimately impinges on the federal revenue as the surrogate for the public interest.

Given the institutional machinery of the legislative process set out earlier, the tax legislative process routinely attaches the dollar value of the impact of a proposed piece of tax legislation on the federal revenues. A proposed change that reduces revenue and breaches the principle of tax equity is considered inimical to the public interest. ${ }^{32}$

28. As the Ad Hoc Committee on Educational Institutions on Copyright Revision urged a specific statutory exemption for multiple copying by classroom teachers, the Association of American Publishers, Inc., and the Authors' League of America, Inc., appeared in opposition. The course of the subsequent negotiations and the guidelines reflecting the ultimate agreement among these interest groups is described in Ralph S. Brown \& Robert C. Denicola, Copyright 353-60 (Foundation Press, 5th ed 1990).

29. See statements of Jon Baumgarten on behalf of the Association of American Publishers, Inc., in S Rep No 425, 98th Cong, 2d Sess 22 (1984).

30. Pub L No 101-650, 104 Stat 5134 (1990). See also H Rep No 101-735, 101 st Cong, 2d Sess 15-17 (1990).

31. See note 24 .

32. The literature of tax policy identifies special interest provisions as private subsidies inconsistent with the public interest being given outside the traditional congressional process of dealing with appropriation measures. As one commentator put it,

[t]he tax subsidies tumble into the law without supporting studies, being propelled instead by cliches, debating points, and scraps of data and tables that are passed off as serious evidence. A tax system that is so vulnerable to this injection of extraneous, costly, and illconsidered expenditure programs is in a precarious state from the standpoint of the basic tax goals of providing adequate revenues and maintaining tax equity. 
Unfortunately, no such refined definition of "public interest" exists for copyright legislation. A recent survey of the economic literature of intellectual property notes the absence of any data showing the efficiency of the incentive created by the patent and copyright statutes. ${ }^{33}$ A legislator in the copyright arena must look instead to a framework of general postulates provided by various informed commentators. For example, Benjamin Kaplan counsels that copyright legislation take account of all interests and be sensitive to changing technology. ${ }^{34}$ David Lange similarly urges legislators to impose the duty of demonstrating a meritorious public purpose on proponents of special treatment. According to Lange, the stated purpose should be required to pass muster under a broader, multi-part test. ${ }^{35}$ Lange's framework was adopted in substantial measure by Congressman Kastenmeier and his staff counsel in explaining the development of the legislation to protect the semiconductor chip industry. ${ }^{36}$ Richard Stern has subsequently refined such general criteria by suggesting that Congress establish guidelines of intellectual property protection for new technologies, but delegate the task of identifying eligible technologies to an executive branch agency for formulation of the specifics of protection. ${ }^{37}$ Stern's approach would serve better to tailor the protective legislation to the new technology and enable Congress to take account of the needs of a particular industry. Ralph Brown has pointed out that in extending protection to new technologies, Congress should be sensitive to the inherent tensions between the rights of the author, the public interest, and the concept of a full, free market for these rights. ${ }^{38}$

From these general postulates, Representative Kastenmeier and his staff counsel have constructed a four-part test for identifying the public interest in proposed intellectual property legislation. First, the proposed legislation must be compatible with the principles and concepts of the existing statutory framework. Second, the proponent must provide a workable definition of the proposed subject matter of protection, including a statement of permissible, non-infringing uses. Third, the proponent must furnish a cost/benefit analysis of the impact of the new protection. Finally, the proponent must

The Economy of Federal Subsidy Programs, Hearings before the Subcommittee on Priorities and Economy in Government of the Joint Economic Committee, 92nd Cong, 1st Sess 48, 49 (1972) (statement of Stanley S. Surrey).

33. Stanley M. Besen \& Leo J. Raskind, An Introduction to the Law and Economics of Intelleclual Property, 5 J Econ Perspectives 3, 4 (1991). But see William M. Landes \& Richard A. Posner, $A n$ Economic Analysis of Copyright Law, 18 J Legal Studies 325 (1989).

34. Benjamin Kaplan, An Unhurried View of Copyright: Proposals and Prospects, 66 Colum L Rev 831, 854 (1966).

35. Copyright and Technological Change, Hearings before the Subcommittee on Courts, Civil Liberties, and the Administration of Justice of the House Committee on the Judiciary, 98th Cong, 1st Sess 57-58, 65-68 (1983) (statement of David Lange) ("Hearings on Copyright and Technological Change").

36. Robert W. Kastenmeier \& Michael J. Remington, The Semiconductor Chip Protection Act of 1984 : A Swamp or Firm Ground?, 70 Minn L Rev 417, 440-42 (1985).

37. Richard H. Stern, The Bundle of Rights Suited to New Technology, 47 U Pitt L Rev 1229, 1262-67 (1986).

38. Ralph S. Brown, Eligibility for Copyright Protection: A Search for Principled Standards, $70 \mathrm{Minn}$ L $\operatorname{Rev} 579$ (1985). 
identify a material contribution of the legislation to the community stock of knowledge, that is, to the public domain. ${ }^{39}$ Overall, the last criterion is dispositive of the decision by the legislator to support the proposal. As Kastenmeier and his counsel put it, "[f]rom a larger political perspective, the greatest betrayal that could ever occur is that Congress would confer protection above and beyond that necessary to stimulate a desired creative activity." 40

Representative Kastenmeier's conduct in achieving these stated objectives can be assessed from the substantial paper trail generated by the legislative process. The 1976 Act, given the extended duration of the deliberations, produced a voluminous legislative history consisting of hearings, commissioned studies, and Copyright Office position papers. ${ }^{41}$ The Chip Act followed this general pattern of extensive hearings.42 Representative Kastenmeier and his committee have also utilized the Office of Technology Assessment to obtain information. ${ }^{43}$ Special commissions and oversight hearings round out the congressional techniques for information gathering. ${ }^{44}$ Taking the 1976 Copyright Act and the Semiconductor Chip Protection Act together shows that the congressman and his committee applied both informative and deliberative legislative techniques in developing these measures.

Distilling the conduct of Congressman Kastenmeier through the prism of the hearings on the 1976 revision of the Copyright Act shows his inclination to seek consensus between and among competing interests. During the course of the deliberations over almost all of the copyright legislation, beginning with the revision, Representative Kastenmeier has responded in the same manner. As one interest group urged its position on a given issue only to be opposed by another interest group, the parties were sent to resolve their differences by compromise. ${ }^{45}$ It is clear that seeking consensus among

39. Kastenmeier \& Remington, 70 Minn L Rev at 440-42 (cited in note 36). 17).

40. Id at 460. This objective is also stated in Commission's Final Report at 13-19 (cited in note

41. See the eighteen volumes compiled by George S. Grossman, Omnibus Copyright Revision Legislative History (Hein, 1976). Congress also utilized industry and legal expertise in dealing with copyright protection of computers by establishing CONTU. See generally Commission's Final Report (cited in note 17).

42. See generally Symposium, The Semiconductor Chip Protection Act and lts Lessons, 70 Minn L Rev 263 (1985).

43. See U.S. Congress, Office of Technology Assessment, Intellectual Property Rights in an Age of Electronics and Information (1986).

44. Computers and Intellectual Property, Hearings before the Subcommittee on Courts, Intellectual Property, and the Administration of Justice of the House Committee on the Judiciary, 101 st Cong, 1st \& 2nd Sess (Nov 8, 1989, March 7, 1990) ("Hearings on Computers and Intellectual Property").

45. In her careful review of the legislative history, Jessica Litman notes that "[t]he statute's legislative history is troubling because it reveals that most of the statutory language was not drafted by members of Congress or their staffs at all. Instead, the language evolved through a process of negotiation among authors, publishers, and other parties with economic interests in the property rights the statute defines." See Litman, 72 Cornell L Rev at 860-61 (cited in note 13). 
opposing groups is a strategy of this representative. ${ }^{46}$ However, the record also shows that Representative Kastenmeier served as more than a passive referee. Professor Litman's description of congressional conduct based on her thorough and thoughtful review of the legislative history of the 1976 Act, can fairly be taken as a description of the conduct of the congressman when she writes,
Congress consistently resisted lobbying over substantive issues, insisting instead that would-be lobbyists sit down with their opponents and seek mutually acceptable solutions. Members of Congress worked very hard on the copyright revision bill. They held repeated, lengthy subcommittee hearings, attended numerous executive sessions, and drafted a flood of committee reports. More important, they encouraged, cajoled, bullied, and threatened the parties through continuing negotiations. They mediated disputes and demanded that combative interests seek common ground. Viable compromises emerged from the interminable negotiations largely because of congressional midwifery. ${ }^{47}$

One example of Congressman Kastenmeier's conduct conforming to the above description is illustrated by his colloquy during the hearings with a representative of the juke box industry, in which he pressed the spokesperson to state the economic consequences of his proposal. ${ }^{48}$

Congressman Kastenmeier and the committee also required special interest groups to arrive at a compromise solution balancing public and private interests in the development of the guidelines on multiple copying by educational institutions. ${ }^{49}$ The special statutory exemption for reproduction by libraries and archives was also reached through negotiation. ${ }^{50}$ In this case, the statute incorporated a provision requiring the Register periodically to report to Congress on the success of the compromise. ${ }^{51}$ These examples support the conclusion that Representative Kastenmeier was sensitive to and vigorous in asserting the need for recognition of the public interest during the 1976 revision.

His approach of seeking consensus and balancing public and private interests is also reflected in subsequent legislation. The issue of moral rights serves as an example. Deliberately omitted in the 1976 revision and vigorously resisted during the deliberations of the Berne Convention Implementation Act in 1988, Congress has since yielded to pressure for a variant of moral rights protection for visual artists. Congress has reacted to

46. In a recent lecture, Representative Kastenmeier outlined his approach to copyright legislation for new technology:

There will be growing reliance on special reports, technological assessments, private negotiations and perhaps national study commissions. . . . Consensus will be the rule rather than the exception.

Robert W. Kastenmeier, Copyright In An Era Of Technological Change: A Political Perspective, 14 ColumVLA J L \& Arts 1, 24 (1989).

47. Litman, 72 Cornell L Rev at 871 (cited in note 13) (citations omitted).

48. Hearings on HR 2223 at 426-27 (cited in note 13).

49. Id at 294-95. See also Hearings on Copyright and Technological Change at 57-58, 65-68 (cited in note 35 ).

50. 17 USC § 108(i) (1990).

51. See Report of the Register of Copyrights: Library Reproduction of Copyrighted Works (1988). 
this in a minimal fashion by extending rights of attribution and integrity to a restricted number of works of visual art, but as legislation separate and apart from Berne considerations. ${ }^{52}$ Congressman Kastenmeier noted the limited scope of this new protection. ${ }^{53}$

Aside from striving for consensus and for recognition of the public interest by special interest representatives, Representative Kastenmeier deserves credit for taking initiatives in the public interest in the absence of special interest prodding. For example, when a recent Fourth Circuit decision announced a clearly perverse interpretation of the first-sale doctrine that effectively barred domestic purchasers of video game electronic equipment from applying the purchased item to the intended use, the Congressman took the initiative in legislatively overruling the decision. ${ }^{54}$

A similar exercise of initiative in the public interest by Kastenmeier is his use of oversight hearings to evaluate the effectiveness of recent legislation. For example, in response to a rising volume of software patent applications that breached the earlier understanding of exclusive copyright protection for software, the Congressman organized hearings to "stimulate debate and to promote understanding, rather than to resolve controversies among competing interests." 55

While overall the evidence supports a finding of exemplary conduct by Congressman Kastenmeier, the record is not without its negative side. There have been occasional lapses, which must be charged to the chairman since they occurred on his watch. Ralph Brown points out that,

Congress ... sometimes does no more than respond to pressure groups. . . A kind of copyright pork-barrel has existed, with exemptions from liability being granted to favored constituents. Thus, after having created a public performance right, Congress created a bundle of full and partial exemptions from liability in section 110 , the public performance pork-barrel. ${ }^{56}$

A criticism of a different order has been voiced by an observer of the Semiconductor Chip Act of 1984, who states that "a technologically naive Congress" provided a legislative solution against chip piracy after the problem had substantially been ameliorated by the natural evolution of process technology. ${ }^{57}$ Mitchell Kapor makes the same point in recent testimony before Representative Kastenmeier's Committee: "[w]ith the

52. The Visual Artists Rights Act of 1990, Pub L No 101-650, 104 Stat 5128 (Dec 1, 1990), codified at 17 USC $\S 106 \mathrm{~A}$ (a) (1990).

53. 136 Cong Rec H13313 (daily ed Oct 27, 1990).

54. Red Baron-Franklin Park, Inc. v Taito Corp., 883 F2d 275 (4th Cir 1989). This decision is effectively reversed by 17 USC $\$ 109$ (e), enacted as part of the Computer Software Rental Amendments Act of 1990, 104 Stat at 5134. The decision had held that the use of an arcade video circuit board constituted an infringing public performance of the rights of the seller of the board. Under the new provision, the owner of a given copy of the circuit board may perform or display the game without permission of the copyright owner of the game.

55. Hearings on Computers and Intellectual Property at 2 (cited in note 44) (statement of Representative Kastenmeier).

56. Brown, 70 Minn L Rev at 593 (cited in note 38).

57. Comment, Five Years Without Infringement Litigation under the Semiconductor Chip Protection Act: Unmasking the Spectre of Chip Piracy in an Era of Diverse and Incompatible Process Technologies, 1990 Wis L Rev 241, 276 (authored by Robert L. Risberg). 
Semiconductor Act ... what has happened is that in some sense it is largely irrelevant now because the techniques that are used to produce functionally equivalent chips don't involve copying of the masks." 58

This latter criticism raises both individual and institutional concerns. Was the Congressman's approach a factor in providing protection after the need for it had passed? Should the institutional machinery of Congress have been assigned the task of determining the timeliness of the industry pressure for protection, given the extended duration of the deliberations?59 It may be that this criticism of the Chip Act illustrates the obsolescence of the traditional congressional mechanism in the face of increasingly complex technology. Legislating about such matters may require modifications in legislative machinery such as those proposed by Richard Stern. ${ }^{60}$

Moreover, it is not clear that the criticism is correct. Subsequent to the appearance of this critical article, industry spokespersons as well as practitioners recorded their disagreement with it by letters to the Committee. ${ }^{61}$ If the criticism has some validity, it relates to the larger congressional problem of legislating about new and complex technology. Further study is needed to determine whether the statute as enacted was an anachronism or whether it successfully provided a needed legal framework for the industry to flourish without conflict.

\section{$\mathrm{V}$}

\section{ConClusion}

The evidence reviewed above establishes Representative Kastenmeier's mastery of both the doctrinal and practical aspects of copyright. The case is made that he should be honored as a distinguished public servant. His record reflects both a concern for the public interest and a sensitivity to the needs of the constituent groups of copyright law.

This laudatory assessment is reinforced by his post-congressional conduct. While a serving member of Congress, Representative Kastenmeier was always scrupulous in avoiding the semblance of impropriety. In his present capacity, he adheres to the highest ethical traditions by refusing to engage in private practice or consulting about these matters. In this way, he continues to provide a model of the best kind of public service.

I am pleased to have this opportunity to participate in this festschrift in Representative Kastenmeier's honor.

58. Hearings on Computers and Intellectual Property at 247 (cited in note 44).

59. For a complete review of the background of this legislation, see Richard H. Stern, Semiconductor Chip Protection 32-41 (Harcourt Brace Jovanovich, 1986).

60. Id.

61. Hearings on Computers and Intellectual Property at 949-58 (cited in note 44). Appendix 4 to these hearings contains copies of letters to Representative Kastenmeier from the Commissioner of Patents and Trademarks, the Register of Copyrights, intellectual property lawyers, as well as industry people in response to his earlier letter requesting their opinions on the efficacy of the Chip Act. These responses uniformly attest to the value of the statute. 
